los aros de cebolla chisporroteando, la hojarasquería que ruge hacia su consumación.

No es hambre lo que bulle en las tripas

de esta olla de invierno, sino la proyección de caldos continuos, la carne blanca y las espinas y huesos, el halo plateado de las hojas, el paisaje en que estamos. No es hambre lo que nos trae aquí, sino el vaho común que se concentra, su producción en todo.

\title{
Plan de Tlacapatla
}

Un jacal en que entráramos, techado de niños, carbón al viento o basurillas en los pajares del maizal. En medio las vacas, a la partida de los peones, sin hibernación ni guarida, olisqueando huellas humanas, ruido sólo nosotros.

En los escombros, un camioncito sin ruedas, mechas de palma, un bule roto y tres piedras tiznadas en señal del hogar.

Sobras de trashumancia, después de la siembra, al cabo de la pizca. 
El Plan ahora un mar dorado en que nos calentamos como mazorcas al sol cuaresmal.

\section{SA TUNA}

Hacia sí misma la cala se recoge, lanza luces desde la coda del invierno, varas en inquieto abandono.

Entre la madera turbia y las barcas gira un aire de aceite crudo, de luz desmantelada.

Sonreímos y nos abrazamos.

Caminamos entre mesas y gente en el hervidero y el pescado.

Eso que fuimos.

Hoy la terraza es un garaje abierto sin nada más que nosotros y una bicicleta roja recargada en el muro. 